University of Wollongong

Research Online

Sydney Business School - Papers

Faculty of Business and Law

6-2011

\title{
Liberty, national security and the Big Society
}

\author{
Alison Green \\ University of Plymouth \\ Nick Johns \\ Mark Rix \\ University of Wollongong, mrix@uow.edu.au
}

Follow this and additional works at: https://ro.uow.edu.au/gsbpapers

Part of the Business Commons

\section{Recommended Citation}

Green, Alison; Johns, Nick; and Rix, Mark: Liberty, national security and the Big Society, Sociological Research Online: 16(2) 2011, 19.

https://ro.uow.edu.au/gsbpapers/37

Research Online is the open access institutional repository for the University of Wollongong. For further information contact the UOW Library: research-pubs@uow.edu.au 


\title{
Liberty, national security and the Big Society
}

\begin{abstract}
The Big Society agenda of the UK Coalition Government has had a significant impact on welfare policy as well as the terms of the debate about how welfare should be provided for and regulated. The ripples have travelled far beyond the UK and similar discussions are occurring in different national contexts. One such has been Australia, where commentators and policymakers are considering the ramifications of a Big Society approach for domestic social policy (Cox 2010). This debate no longer focuses on the 'New Public Management' agenda with its emphasis on outsourcing to third and private sector providers and the creation of market-like structures and mechanisms for welfare provision. Instead, there is a renewed interest in strengthening communities and developing the voluntary capacities within them to enable them to shoulder the responsibility for service delivery, community safety and reinforcing social cohesion. Nevertheless, effectively the objectives are the same: smaller government, reduced social expenditures and an individualistic society.
\end{abstract}

\section{Disciplines}

Business

\section{Publication Details}

Green, A., Johns, N. and Rix, M., Liberty, national security and Big Society, Sociological Research Online, June 2011, 16(2), 19. 


\section{Liberty, national security and the Big Society}

Alison Green, Nick Johns and Mark Rix

(a version of this paper was published in Sociological Research online 16 (2) 19 (June 2011) 


\section{Liberty, national security and the Big Society}

\section{Introduction}

The Big Society agenda of the UK Coalition Government has had a significant impact on welfare policy as well as the terms of the debate about how welfare should be provided for and regulated. The ripples have travelled far beyond the UK and similar discussions are occurring in different national contexts. One such has been Australia, where commentators and policymakers are considering the ramifications of a Big Society approach for domestic social policy (Cox 2010). This debate no longer focuses on the 'New Public Management' agenda with its emphasis on outsourcing to third and private sector providers and the creation of market-like structures and mechanisms for welfare provision. Instead, there is a renewed interest in strengthening communities and developing the voluntary capacities within them to enable them to shoulder the responsibility for service delivery, community safety and reinforcing social cohesion. Nevertheless, effectively the objectives are the same: smaller government, reduced social expenditures and an individualistic society.

\section{Big Society}

'Big Society' is central to the current Coalition government's agenda. The ideas of community participation and increased voluntarism are not unique to this government, however. The previous Labour government also encouraged community participation through their 'citizenship' programme. However, citizenship was linked to duty and responsibility and the 'Welfare to Work' programme. Community participation was encouraged to strengthen communities and to provide the necessary 'social glue' for a peaceful, cohesive society. In that way fewer resources would be needed for policing and resolving social problems. The 'Big Society' may seem to be rooted in very similar ideas but it has some important differences. 
The current ideas can be traced back to the Thatcher years when arguments were made for the involvement of the voluntary sector based on increasing the diversity of provision and participation (Hadley \& Hatch 1981). The political right also argued for the involvement of the voluntary sector as a competitor and substitute for the public sector (Brenton 1985). Throughout the 1980s the Thatcher governments encouraged the voluntary sector to take on greater responsibility and funding increased to over $£ 4$ billion by 1987 (Home Office 2004). Charitable donations were also incentivised at this time through the tax system. Perhaps the most concrete example of support for voluntary provision was the 1988 housing legislation which transferred power away from local authorities to voluntary sector housing associations. In addition, the introduction of market-led arrangements for the provision of community care drove provision away from the public sector toward the voluntary and private sectors.

The Coalition Government's vision of the Big Society is not entirely clear, but according to Prime Minister David Cameron it is based on the premise that 'we can all do more'. In this sense, the Big Society is a mechanism which enables our civic capacity to grow, in order to solve problems that were previously addressed by the State (Rowson et al. 2010). For the Conservative Party the 'Big Society' is more than voluntarism, it is about unlocking social capital. For them social capital is about personal networks which are not controlled by the State. They emphasise the importance of groups which receive no State funding and rely totally on volunteering or locally raised funds. This is wrapped up in rhetoric around freedom from State control and liberal individualism.

We argue in this paper that, in the wake of the 9/11 attacks in the United States, domestic counter-terrorism policy has emerged as a key area in which tensions between 'governmental paternalism' and individual responsibilities are most evident. Since then governments in the West have evidently come to believe that in effect 'national security' means the protection of their countries from the threat of terrorism. Many of these governments, including the British and Australian, apparently assume they have a moral obligation to the countries and cultures who are believed to be 
most susceptible to terrorist contamination to 'save them' via liberal Western values and institutions delivered by means of 'the good war' (Dexter 2007) or crusade. There is a clear synergy here, for the gift of 'salvation' is also believed to be the West's best defence against foreign terrorism. While the global 'War on Terror' sets the international context for this paper, it is chiefly concerned with comparing British and Australian domestic counter-terrorism policy in order to draw out the connections between the two but also the points of differentiation. Even though we will consider important issues such as their seemingly common attitudes towards Islam (Poynting \& Mason 2006) and the convergence in ideas about the perceived threat of multiculturalism (Kirkup 2011), the central question we pose here is this: does the Big Society agenda of the Coalition Government provide a template for Australia to emulate to give substance to its self-proclaimed commitment to human rights and the rule of law?

\section{Great Britain and Counter-Terrorism}

The Blair Administration, in power at the time of $9 / 11$, responded vigorously to what was perceived to be a new and more dangerous security environment. Its foreign policy was largely driven by events abroad that it believed threatened the country's security and broader interests. The expeditions to Iraq and Afghanistan were two of the incursions that demanded most attention, and human and material resources. The former was predominantly based on the pretext of the need to eliminate Saddam Hussein's non-existent weapons of mass destruction, and his imagined links to al Qaeda, the latter on the pretext of the need to neutralise and eliminate the global terrorist threat at source. On the domestic front, a whole raft of new legislation was introduced enabling the British State to deal with the home-grown and imported terrorist threats (Greer 2008). This new legislation really wasn't so new, based as it was on the framework developed during the Troubles for countering the Irish terrorist threat within mainland Britain, in Northern Ireland and emanating from the Republic of Ireland (Trimble 2011; Hillyard 1993). The focus of the measures adopted to counter the new threat of course moved from Irish Republicanism and nationalism to Islamic fundamentalism and extremism or, more simply, just Islamism (Poynting \& Mason 2006; Sayyid 2003; Spalek 2007). 
We do not have sufficient space to fully outline the raft of counter-terrorism legislation and policy enacted by New Labour but the key instruments included:

- The Terrorism Act 2000 - This Act defined an 'action' or 'the mere threat of action' as that which advances a cause that attempts to influence the government and that falls into one of several categories including serious damage to property.

- The Anti-Terrorism, Crime and Security Act 2001 - The key provision for our purposes was the desire to remove foreign individuals suspected of international terrorism, or to detain them indefinitely where this was not possible, all at the behest of the Home Secretary.

- Prevention of Terrorism Act 2005 - faced with a judiciary armed with European legal instruments New Labour used this Act to replace pre-charge detention with control orders.

The impact on the Muslim community and black and minority ethnic groups (BMEGs) has been significant. A key dimension of this has been a process of demonisation which has been cleverly executed by the right-wing tabloid press, culminating in a claim that fundamentalists were aiming to sabotage the recent Royal wedding (Daily Mail 2011). Predictably this has led to abuse and harassment on the streets by the police formalised in stop and search, and supported by more widespread harassment (Sivanandan 2006). Just as with the legislation introduced in Northern Ireland, the measures aimed at specific groups have the potential to creep outwards to incorporate the general population (Hillyard 2005). This has meant detention without charge, jury trials removed for specified cases, facts concealed from detainees, suspects subject to house arrest or curfew and continual attempts to extend periods of detention (Bright 2008). At the height of this activity it was suggested that: 'Blatant violations of due process are becoming a normal part of British law' (Ackerman 2006: 42). 
In 2010 New Labour were finally ejected from office by a Conservative/Liberal Democrat Coalition promoting the establishment of the Big Society to repair what Cameron had in opposition called the Broken Society. As set out above the key components of this ideological project are a desire to revive civic responsibility through voluntarism (again), to reduce public expenditure and to prioritise liberty, though of course to the classical Liberal these latter points are inextricably linked; reducing public expenditure is an important measure to increase individual liberty. In the context of the Big Society and the Coalition Government's approach to counter terrorism this has had significant policy implications and consequences.

Perhaps one of the most noteworthy changes has been the introduction of the Protection of Freedoms Bill in an attempt to reclaim some of the ground that had been lost under New Labour. With reference to counter-terrorism under this legislation terror suspects can now be detained for 14 days without charge compared to 28 previously; the use of DNA and CCTV cameras has been constrained; and stop and search laws are restricted. Another important dimension of the Big Society agenda has been the reduction of police numbers as part of a broader drive to reduce government spending. This may suggest that the new Government recognises that a number of provisions and counter terrorism laws really provide little or no protection from the terrorist threat or that the level and imminence of the threat were exaggerated. Another dimension of this relates to the expectation that citizens ought to take greater responsibility for their welfare and by extension their security through the promotion of citizen patrols; that is the furthering of the outsourcing of police functions to individuals in their communities, such as the Street Pastors initiative whereby Christian groups patrol the night-time economy, and, more recently, schools (Johns et al. 2009; McGuiness 2009). This movement away from anti-terror impositions on liberty is a fragile development that, in the face of a raised terror alert or an actual event, will no doubt quickly bring about a return to the status quo ante. Indeed, even an event as apparently benign as the Royal Wedding saw a determined police campaign to stamp out dissent and expressions of republican sentiment by pre-emptive strikes against likely protesters and enforcing exclusion 
zones around certain locations (Aitchison 2011). Labour's Serious Organised Crime and Police Act was tremendously helpful to the police in effecting this response. In the wake of the unlawful execution of Osama Bin, even more severe pre-emptive actions can be expected.

\section{Australia and counter-terrorism}

Like the Blair Administration, the Howard Administration in Australia responded energetically to the events of $9 / 11$ and the changed security environment that ensued. Australia willingly joined the 'Coalition of the Willing' and went to war in Iraq for essentially the same reasons as had the British, and also participated in the Afghanistan incursion on an almost identical pretext. As in Britain, Australia adopted a raft of counter-terrorism laws that, nevertheless, outstripped the Mother country's in volume and harshness. There are, however, some even more notable differences between the two countries' approach to counter-terrorism. Unlike Britain, Australia has never faced a threat like that of Irish Republicanism and the atrocities carried out on mainland Britain in its name during the Troubles. And, Australia did not introduce a Human Rights Act as Britain did in 1998 (effective from 2000) which to an extent moderated the severity of the measures contained in the counter-terrorism legislation that, in any case, was subject to review by the European Human Rights Court. Australian Governments have steadfastly refused to adopt a bill of rights which may have moderated its tough counter-terrorism approach.

It is important to understand some of the events which helped to shape the regional and historical context within which Australia's counter-terrorism regime was developed. To begin with, Indonesia is Australia's largest neighbour and has the world's largest Muslim population. It is the home of Jemaah Islamiyah (JI), a terrorist organisation committed to violent jihad and with links to al Qaeda. JI was responsible for a number of attacks conducted over the past 9 years that on occasion directly targeted Australians or Australian interests (for details, see Australian Government 2010). Nevertheless, Australia has never experienced a terrorist attack on its own territory and the threat is currently rated at 'medium' by the Australian Government 
(Swan 2011). In other words, the size and severity of Australia's counter-terrorism regime are completely out of proportion to the level of threat it faces.

Australia's first counter-terrorism bill was introduced into Parliament in 2002 (the Security Legislation Amendment Act) which, amongst other things, defines a 'terrorist act' so broadly that it criminalises, and subjects to severe penalties, any actions taken in support of a political organisation that engages in 'physical resistance' against an existing government in Australia or overseas (Rix 2006). For the remainder of the Howard Administration's time in office there was a veritable avalanche of counter-terror bills, totalling 44 separate pieces of legislation. George Williams has aptly described this as a 'frenzy of lawmaking (Williams 2011).'

It is not only the sheer quantity of Australia's counter-terrorism legislation that is exceptional, the measures introduced by the legislation are even more out of the ordinary. These include removal of the right to silence, detention without trial extending to detention of non-suspects in secret merely for intelligence-gathering purposes, and infringements on media freedom and freedom of expression more generally (see Rix 2008 and Rix 2011). As in Britain, Muslim groups and communities are at greatest risk from the persecution, harassment and arbitrary detention permitted in the legislation under the pretext of preventing terrorism and protecting national security (see, e.g., Howie 2005).

In March 2010, the Labor Government introduced the National Security Legislation Amendment bill into the Parliament which many vainly hoped would water down some of these provisions. The Bill implemented the recommendations of several inquiries and reviews conducted over the past several years that considered some of the more important pieces of legislation underpinning Australia's counter-terrorism regime. The Bill passed through Parliament in November 2010 and contains amendments including the establishment of a maximum 7 day limit on the detention period that however can be 'disregarded' when a person is arrested for a terrorism offence. The Federal Attorney-General Robert McClelland commented that the Bill 'seeks to achieve an appropriate balance between the Government's responsibility to protect Australia, its people and its interests and instilling confidence that our 
national security and counter-terrorism laws will be exercised in a just and accountable way (McClelland 2010).' However, the Bill fails, for example, to revoke the power given to the Australian Security Intelligence Organisation (ASIO, Australia's domestic intelligence agency) to detain for up to 7 days and interrogate individuals who are not even suspected of any terrorist offence simply to collect unspecified intelligence.

\section{Discussion: Interrogating the Big Society}

One of the more interesting points to be noted is that the reforms to Britain's counterterrorism regime lie outside of the Big Society agenda. Indeed, in spite of the overblown rhetoric, the Big Society appears to have a fairly narrow focus. This is the Government's apparent desire both to transfer responsibility for social welfare from the public sector to the community through the promotion of volunteerism, and, to reduce public expenditure. This demonstrates that policy-making is actually driven by competing practical realities, that grand visions extend only so far as these realities allow, and that even where intersections exist between different policy components, such as reducing public spending, they are not always entirely coherent or consistent. Although the retreat from New Labour's counter-terror legislation has significant funding implications, for example the impact on the police service, it would be hard to see this as the principal driver of these developments. What this may mean for the political right is that the divisions between the neo-Conservative and neo-Liberal tendencies visible during Thatcher's stewardship and which caused Major to beg his party 'not to tie my hands' have not been eradicated by the adoption of the Big Society (Levitas 1986; Gamble 1988).

What is important to realise from the point of view of this paper is that even if the Australian Government was serious about amending, and moderating, the country's counter-terrorism regime there is little by way of inspiration, direction or example that it would find in the UK's Big Society agenda. This is because the reforms to the British counter-terrorism regime are motivated by intentions that have little in common with those that drive the Big Society, even where principles happen to coincide such as between small government and individual liberty. Such 
coincidences cannot erase the fact that for individual liberty to have any practical meaning and outcomes individuals have to have genuine opportunities for meaningful employment, adequate incomes, good housing, quality education and life-long learning. After all, it is the availability of these opportunities which not only enables individuals to live full and rewarding lives but also gives them hope for their children's future. The relationship is a direct one for such opportunities diminish as the State, and its social expenditures, wither.

If this is so, then it is clear that countering terrorism has not been high on the Government's agenda, for the threat is not as great as it was once portrayed. Therefore, either the threat has declined since the election of the Coalition Government or it was never as great as New Labour maintained. Seen in this light, the attacks of July 2005 on London's public transport system were far more the exception than the rule. However, given the recent execution of Osama Bin Laden, we may see this situation change with a return to much more visible security controls amongst a host of other draconian measures.

\section{Conclusion}

The Big Society agenda of the UK Coalition government has made a major impact on domestic social policy, but the ideas associated with it have travelled far beyond these shores. One of the nations currently considering its potential is Australia. In order to contribute to this debate we have focused on the area of anti-terror policy, largely because the two countries were involved in the post-2001 'War on Terror' and both implemented a raft of legislation designed to protect their citizenry from similar attacks. While the UK did influence Australian policy early on, it is fair to say that Australia eventually went much further in content and coverage. With the arrival of the UK Coalition the counter-terror measures introduced by New Labour were quickly targeted for amendment. 
Given the tendency to imitate the UK in this area can the Australian minority Labor Government (assisted by the Greens and Independents) be expected to follow suit, and if so, does the Big Society offer something worth emulating? Our view is that the counter-terror measures show the limits of the Big Society, that in fact they are not part of that agenda at all. On the one hand it reflects the neo-Liberal commitment to liberty as the primary human right, along with the corresponding reduction in public expenditure, and on the other, it underlines the reality that either the terror threat has lessened, or, that it was exaggerated from the beginning. As an aside there is an interesting anomaly when we consider terrorism and the terror networks. Many of the terrorist networks conform perfectly to the textbook examples of social networks and capital. They are built upon groups of like-minded people co-operating to pursue their own interests. Somewhat bizarrely, then, by promoting the ethos of social capital building the Government are actively encouraging disruptive elements in society to get together and create powerful networks and social capital. In this way social capital is not a force for creating social cohesion and 'social glue', but becomes a force for protest and disruption.

Ultimately, we would argue, the Big Society has little to offer Australia or any other society, unless they wish to establish a society with excessive and growing inequalities, restricted social mobility and facing terror of an utterly different kind. If Orwell were to assess the Big Society as an idea he would undoubtedly regard it as an example of a phrase representing its complete opposite - it heralds instead a withered, hollowed out society where 'we are all in it together' has become the most hollow phrase of all. 


\section{References}

ACKERMAN B. (2006) Before the next attack. The New Statesman. July 2006. pp. 38-42.

AITCHISON G (2011) Political policing in Britain ahead of the Big Day. OpenDemocracy. April $2011<$ http://www.opendemocracy>

AUSTRALIAN GOVERNMENT (2010) Counter-Terrorism White Paper: Securing Australia/Protecting our Community.

$<$ http://www.dpmc.gov.au/publications/counter terrorism/docs/counterterrorism white paper.pdf>

BRENTON M (1985) The Voluntary Sector in British Social Services. London: Longman.

BRIGHT M (2008) British Jihad: Why our anti-terror strategy isn't working. New Statesman. April 2008. pp. 10-12.

COX E (2010) Put the big society (back) on the agenda again. Crikey, December 2010. <http://www.crikey.com.au/2010/12/09/eva-cox-put-the-big-society-back-onthe-agenda/s

DAILY MAIL (2011) Militant Muslim warns Royal Wedding terror attack is 'highly likely. MailOnline. <http://www.dailymail.co.uk/news/article-1372291/Muslim-AnjemChoudary-warns-Royal-wedding-terror-attack-highly-likely.html>

DEXTER H (2007) 'New War, Good War and the War on Terror: Explaining, Excusing and Creating Western Neo-interventionism', Development and Change, vol. 38, no. 6 pp. 1055-1071.

GAMBLE A (1988) The Free Economy and the Strong State: The Politics of Thatcherism. London: Macmillan.

GREER S (2008) 'Human Rights and the Struggle against Terrorism in the United Kingdom', European Human Rights Law Review, vol. 2, pp. 163-172.

HADLEY R and HATCH S (1981) Social Welfare and the future of the State. London: Allen and Unwin. 
HILLYARD P (1993) Suspect Community: People's Experience of the Prevention of Terrorism Acts in Britain. London: Pluto Press with Liberty

HILLYARD P (2005) 'The "War on Terror": Lessons from Ireland', $<$ http://www.ecln.org/essays/essays-1.pdf>

HOME OFFICE (2004) Central government funding of voluntary and community organisations, $1982 / 83$ to $2001 / 02$.

HOWIE L (2005) The threat of terrorism and social change. Human Rights Defender Special Issue: The Anti-Terrorism Bill. November/December 2005, no. 2 pp. 22-23.

JOHNS NR SQUIRE G AND BARTON A (2009) 'Street Pastors: from Crime Prevention to Re-moralisation?', British Society of Criminology online journal, vol. 9, <http://www.britsoccrim.org/volume9/3.Johns09.pdf>

KIRKUP J (2011) Muslims must embrace our British values, David Cameron says. The Telegraph, 5/2/11.

LEVITAS R (Ed.) (1986) The Ideology of the New Right. Cambridge: Polity Press.

McCLELLAND R (2010) National Security Legislation Passes Parliament $<$ http://www.attorneygeneral.gov.au/www/ministers/mcclelland.nsf/Page/MediaRelea ses 2010 FourthQuarter 15November2010-

NationalSecurityLegislationpassestheParliament>

McGUINESS J (2009) Walking the streets with the flip-flop angels. Church Times. January 2009. pp. 20-21.

POYNTING S and MASON V (2006) "'Tolerance, Freedom, Justice and Peace"?: Britain, Australia and Anti-Muslim Racism since11 September 2001', Journal of Intercultural Studies, vol. 27, no. 4 pp. 365-391.

ROWSON J BROOME S and JONES A (2010) Connected Communities: How social networks power and sustain the Big Society. RSA Report $<$ http://www.thersa.org/projects/connected-communities> 
RIX M (2008) 'Australia and the "War against Terrorism": Terrorism, National Security and Human Rights', Crimes and Misdemeanours: Deviance and the Law in Historical Perspective, no. 2/1 pp. 40-59

RIX M (2011) 'Counter-terrorism and information: The NSI Act, fair trials and open, accountable government', Continuum: Journal of Media and Cultural Studies, vol. 25, issue 2 pp. $285-297$.

SAYYID S (2003) A fundamental fear: eurocentrism and the emergence of Islamism. London: Zed Books.

SIVANANDAN A (2006) 'Race, terror and civil society', Race \& Class, vol. 47, no. 3 pp. 1-8.

SPALEK B (2007) Muslim Communities and Counter-Terror Responses: "Hard" Approaches to Community Engagement in the UK and Australia. Journal of Muslim Minority Affairs, pp. 185-202.

SWAN W (2011) Media Release: Appointment of the Independent National Security Legislation Monitor <http://www.nswbar.asn.au/circulars/2011/apr/walker.pdf>

TRIMBLE V (2011) Anti-Terrorist Legislation in the United Kingdom: Continuity and Change. Unpublished PhD Thesis, School of Law, University of Bristol, UK

WILLIAMS G (2011) Britain is taking another look at its anti-terrorism laws, so why can't we? The Sydney Morning Herald, 14 April <http://www.smh.com.au/opinion/politics/britain-is-taking-another-look-at-itsantiterrorism-laws-so-why-cant-we-20110413-1ddzc.html> 